\title{
Editorial
}

\section{SCIENTIFIC PUBLISHING: VITAL FOR PUBLIC HEALTH AND AUTHORS}

What happens when you, the potential authors of scientific research study, decide not to write and submit your findings for peer review publication? Nothing. That "nothing" joins the countless invisible romantic mountains of lost learnings and the trash of obsolescence. The vital interest of public health is not served, and you lose the chance to contribute to the advancement of scientific learning and to your consequent professional development. Even with thought, discussion, lab or field work and analysis, if not written or published, it is still nothing, nonexistent.

There is no wish to stress you or anyone with the aphorism "Publish or Perish." No one is perishing here other than the currency of latest data findings and potential valuable insights. When study findings are not published, the evidence generated cannot be literally "seen!" How can other researchers build on that unpublished evidence?

To advance the science and practice of public health, you need to write and publish your findings and insights. Positive and negative outcomes are equally important. You build on the knowledge of others and add your own perspective. Sharing new methods, applications, and results promote scientific learning. After all, aren't you and we, in our chosen space of promoting healthy populations?

Research and publication enhance your training, clinical care, and also teaching. On top of that, as successfully published authors with now "perpetualized" names in the field, your peer-reviewed articles raise your credibility as experts in your areas of discipline. Naturally, recognition of your expertise also benefits your sponsoring organizations which can then expand and strengthen their institutional research partnerships and funding sources from all over the world.

JMUST exists because it values deeply the cause and interest of public health through publishing. We enjoin you to write, publish, and be instruments of sharing knowledge to protect and improve general health. With dedicated authoring and publishing technology platforms that JMUST has, the effort of writing and publishing is less daunting and even friendly.

Coronavirus at Manila's doorstep notwithstanding, JMUST releases our latest issues. We have six research articles, one protocol for systematic review and one news article.

Our editorial team and peer reviewers worked hard as usual, dedicating time and space in their busy schedules to get this issue out on time.

Keep Safe everyone!

(i) Open Access This article is licensed under a Creative Commons Attribution 4.0 International License, which permits use, sharing, adaptation, distribution and reproduction in any medium or format, as long as you give appropriate credit to the original author(s) and the source, provide a link to the Creative Commons license, and indicate if changes were made. The images or other third party material in this article are included in the article's Creative Commons license, unless indicated otherwise in a credit line to the material. If material is not included in the article's Creative Commons license and your intended use is not permitted by statutory regulation or exceeds the permitted use, you will need to obtain permission directly from the copyright holder. To view a copy of this license, visit http://creativecommons.org/licenses/by/4.0/. 